American Journal of Agricultural and Biological Sciences 7 (1): 28-35, 2012

ISSN 1557-4989

(C) 2012 Science Publications

\title{
A Note on the Analysis of Time Cost by Difference of Transaction System in the Agricultural Wholesale Market of Korea
}

\author{
${ }^{1}$ Yoon-Doo Kim and ${ }^{2}$ Seok Yoon \\ ${ }^{1}$ Department of Food and Resource Economics, Konkuk University, \\ 322 Danwol-Dong, Chungju-Si, Chungcheonbuk-Do, 380-701, Korea \\ ${ }^{2}$ Korea National Assembly, 1 Yoido Dong, Youngdeungpo-Ku, Seoul, 150-703, Korea
}

\begin{abstract}
Problem statement: The purpose of this study is to prove objectively that the market-wholesaler system, introduced to agricultural wholesale market in Korea for the first time, has better operational efficiency than the existing auction system. From an analytical viewpoint, we estimated the time value of two transaction systems at the agricultural wholesale market using the calculation methods of the congestion cost and the accumulation cost, and estimated the operational efficiencies divided by product family and item. Approach: We used data from the Statistical Resource of Agricultural and Marine Wholesale Market by Year for the research conducted in this study. Results: As a result, we were able to analyze and conclude that the market-wholesaler system had a relatively lower time cost than the auction system by utilizing the time required from the agricultural carrying-in to the preparation for sale by the transaction system at the agricultural wholesale market and calculating the total time cost for 16 main items into the amounts. These results prove that the market wholesaler system has a better efficiency than the auction system. Conclusion: Therefore, if the market-wholesaler system can be enlarged and introduced into Korea's 32 agricultural wholesale markets as the policy implicates by the study results, we can conclude that the transaction efficiency within the agricultural wholesale market will be better and it will contribute to enhancing the efficiency of the whole agricultural and fishery distribution industry.
\end{abstract}

Key words: Agricultural wholesale market, time cost, auction system, transaction system

\section{INTRODUCTION}

After the urgent change of the agricultural and fishery distribution environment and the opening of the distribution market, the public wholesale market that plays a central role for the agricultural and fishery distribution could not respond to the change of the distribution condition actively due to the inflexibility of operations, the possible need to minimize functions, and because the priority of the wholesale market was gradually on the rise. Therefore, as to whether we can acquire the competitiveness in the agricultural distribution fields or not by enhancing the efficiency of the agricultural wholesale market is on the rise as the main subjects, many discussions have been conducted for the transaction system within the wholesale market.

As a result, a new distribution subject, called the market wholesaler was introduced into the public wholesale market due to the revision of Year 2000 Act on Distribution and Price Stabilization of Agricultural and Fishery Products (Kim and Kwon et al., 2005).

Market wholesaler is the corporation appointed from the establisher of the agricultural and fishery wholesale market and purchasing, selling to be entrusted, or mediating the agricultural and fishery and it means system like the wholesaler of the agricultural wholesale market in America.

In June 2004, the first substantial marketwholesaler system in Korea was introduced and operated at Gangseo agricultural wholesale market. Gangseo agricultural wholesale market operates the market wholesaler system and the auction system at the same time and it is the only place operating the market wholesaler system in Korea. The system operation of the market-wholesaler system is evaluated positively in various parts currently but there were many concerns regarding the operational efficiency when it was first introduced, including the issue of time reduction (time from the carrying-in to the preparation for sales) for the system operation. It makes the proof of efficiency for the market-wholesaler system operation possible objectively.

In this study, we estimated the time reduction for the transaction system operation, one of the factors for the enhancement of the efficiency according to the introduction of the market-wholesaler system, through the calculation of the congestion cost and the

Corresponding Author: Yoon-Doo Kim, Department of Agricultural Economics, Konkuk University, 322 Danwol-Dong, Chungju-Si, Chungcheonbuk-Do, 380-701, Korea 
accumulation cost, and estimated the amount of the occurred operation efficiency, comparing it with the existing auction method, calculating the congestion cost and the accumulation cost divided by the product family and the item. Also, we attempted to convert the cost estimates into the amount and find the economic needs. The purpose of this study is to suggest the necessary political implications with the results of these estimates.

\section{MATERIALS AND METHODS}

Precedent studies and analysis methods: In the case of Korea's agricultural wholesale market, it is common knowledge that the road transportation for the agriculture is widely used. When we use it as the premise, as the congestion accumulation cost are occurred due to the inefficiency of the system operation, we can calculate the cost by dividing into the time cost for the product and the vehicle operation cost for the truck occurred as the queuing cost.

Precedent studies: For the estimates of the time cost, there were many studies related to ships and the traffic congestion for the ground transportation such as roads and ships. For the estimates of the economic value for the demurrage and accumulation time based on this study, the studies of Goss and Mann (1977) were representative. It was estimated from the Long-Run Opportunity Cost (LROC) formula that the ship and freighters have round the world-bank after that time. The methodology of Goss and Mann (1977) estimated the cost based on the demurrage and accumulation at the British Ports in 1970, using the same LROC formula stated above. Furthermore, Jansson and Shneerson (1982) considered the increase of the freight treatment cost and the ship service time, caused by the saturation point of the facilities as the congestion cost without the distinction of demurrage and accumulation.

In Korea, the studies of Chang, Young-Tae and Sung-Gui (1993) estimated the reduction effects of the ship queuing cost and general port cost according to development of that harbor as the demurrage and accumulation cost as a part of the economic analysis when we perform the harbor investment business. Also, KMI (2002) estimated the economic cost according to demurrage and accumulation using the compiled resources from eight domestic harbors (Pusan, Incheon, Kwangyang, Ulsan, Donghae, Gunsan, Mokpo, and Phohang) with the serious ships condition based on Goss and Mann (1977) study methods in the Study on the Economic Effects of Port Industries.
However, the precedent study estimating the economic cost directly according to the difference of transaction system for the agricultural and fishery wholesale market was not performed. Therefore, this study analyzed the time cost according to the difference of the transaction system at the agricultural and fishery wholesale market based on the precedent study of the port.

Estimation of congestion cost: We estimated the congestion cost using the theory and the methodology of Goss and Mann (1977); Chang, Young-Tae and Sung-Gui (2002) and Goss (1974). The daily Long-Run Opportunity Cost (LROC) for the truck can be calculated by the formula shown below Eq. 1:

$\mathrm{LROC}=\frac{\mathrm{CC}+\mathrm{OC}}{365}=(1+2)$

Capital Charge Eq. 2:

$$
\mathrm{CC}=\frac{\frac{\mathrm{Co}}{1-(1+\gamma)^{-\mathrm{n}}}}{\gamma}
$$

Co $=$ initial capital cost

$\mathrm{n}=$ durable years of the truck

$r=$ social discount rate

Operating Cost $=\mathrm{W}+\mathrm{FC}+\mathrm{I}+\mathrm{MC}+\mathrm{T}+\mathrm{GC} \ldots$

$\mathrm{W}=$ Wage

$\mathrm{FC}=$ Fuel cost

$\mathrm{I}=$ Insurance

$\mathrm{MC}=$ Maintenance cost

$\mathrm{T}=\mathrm{Tax}$

$\mathrm{GC}=$ General cost

As the LROC can be calculated with the sum of the Capital Charge (CC) and the Operating Cost (OC), the yearly capital charge will drive the shadow price as the level making the profits discounted at the level of the given production amount to coincide with the discounted cash operating cost and the capital cost correctly. Meanwhile, the yearly operating cost consists of the fuel cost, insurance, maintenance cost, tax, and general cost as well as the wage needed for the operation of the truck. In conclusion,

$$
\mathrm{LROC}=\frac{1}{365}\left[\left(\frac{\mathrm{Co} . \gamma}{1-(1+\gamma)^{-\mathrm{n}}}\right)+\mathrm{W}+\mathrm{FC}+\mathrm{I}+\mathrm{MC}+\mathrm{T}+\mathrm{GC}\right]
$$

From here, the annual capital charge is expressed as the annual equal cost equivalently occurred during the durable years of the truck to be equal to the capital cost. Namely, when the capital charge is summed up to 
take back the investment cost of the truck, if expenses of the equal cost are converted into the current values, it will be the same as the initial capital cost.

Estimation method of accumulation cost: The congestion cost includes the resident cost with the condition that the truck did not load the goods; however, when the truck queues with the loaded goods, the social chance cost called the accumulation cost is occurred along with the congestion cost. It commonly reflects social discount rate. The daily resident time cost (Accumulation cost) of the product can be calculated by the economic value of that year's freight $\times$ social discount rate $\div 365$ days.

Furthermore, the accumulation cost per time of the product can be calculated by economic value of that year's product $\times$ Social discount rate $\div$ (365 days $\div 24$ h). Drawing data from the internal resources of the Seoul Agricultural and Marine Products (public) Corporation and the official statistical resources of The Ministry for Food, Agriculture, Forestry and Fisheries, the economic value of the product can be calculated with the quantity of transactions and the amount of the vegetables and fruits mainly treated by the market wholesaler at Gangseo agricultural wholesale market.

$$
\begin{aligned}
& \text { Accumulation cos t per day } \\
& =\frac{\text { Com modities value } \times \text { social discount rate }}{365} \\
& \text { Accumulation cos } t \text { per time } \\
& =\frac{\text { com modites value } \times \text { social discount rate }}{365 \times 24}
\end{aligned}
$$

\section{RESULTS}

Estimates of congestion cost: The congestion cost can be calculated by adding the annual capital charge to the annual operating cost. To calculate the annual capital charge, it is desirable to invest and apply the durable years of the truck and the initial capital cost, but we used the depreciation expenses of 1,595,608 KRW for the most adjacent truck due to the restriction for various conditions. It applied the depreciation expenses of the ground transportation (person) used in year 2007. Also, when we use this method, there is the inconvenience of having to calculate the depreciation expenses and the interest costs separately, but it can be more realistic applying methods with the given condition (Table 1-5).

Meanwhile, when we calculate using the depreciation expenses, the annual congestion cost (Long-Run Opportunity Cost) of the truck was estimated at a total of $39,080,000 \mathrm{KRW}$ by adding the annual capital cost $1,595,608 \mathrm{KRW}$ to the annual operational cost of 37,484,043 KRW.

As the transaction quantities of year 2007 for the Gangseo agricultural wholesale market totaled 499,059 tons and the transaction records for the marketwholesaler totaled 251,234 tons. It represented about $50.3 \%$ of the total transaction quantities. The number of vehicle related to the market wholesaler of total parked vehicles at Gangseo agricultural wholesale market based on data from 2007, can be calculated by the following formula and it was calculated as approximately 532 vehicles.

Number of vehicle related to the market wholesaler $(2007)=$ Transaction quantities of market wholesaler $\div$ Transaction quantities of Gangseo agricultural wholesale market $\times 1$ day parking vehicle $\times$ Number of annual transaction per day $\div 365$ days.

Finally, the daily congestion cost of the truck was estimated to be as about 56,960,000 KRW when we divide $(39,080,000 \mathrm{KRW} \times 532$ vehicles $)$ by 365 days with the following formula 3. Eq. 3:

Daily congestion cost of truck

$=($ LROC of truck $\times$ Number of trucks $) / 365$ days

\section{Estimates of accumulation cost:}

Calculation of value for carrying-in product: When we see the transaction results of the market wholesaler (Gangseo agricultural wholesale market) in 2007, the total transaction quantity was 251,234 tons, the transaction cost was $349,402,000,000 \mathrm{KRW}$, and the unit cost was calculated as average of 1,390,743 KRW per 1 ton, as stated below in Table 4 .

Residence time cost for products (Accumulation cost): To calculate the stay time cost (i.e., accumulation cost) of the market wholesaler products of Gangseo agricultural wholesale market, the social discount rate of $5.5 \%$ is applied, factoring in the official rate of the Bank of Korea, realistic interest on the loan, and the discount rate applying to various studies conducted recently. The accumulation cost of the whole average for the market wholesaler is calculated at 52,650,000 KRW per day, and 2,194,000 KRW per time. The social discount rate is the social chance cost for the capital applied to convert the cost and the convenience occurred at the different times respectively from the economic analysis into the current values. The social discount rate is changing according to the times and it remains at $5.5 \%$, the rate Korea Development Institute (KDI) has applied from 2007 to the present time. 
Am. J. Agri. \& Biol. Sci., 7 (1): 28-35, 2012

Table 1: Calculation of annual operation cost of the truck (60312) (Data based on year 2007)

\begin{tabular}{lrl}
\hline Division & Annual Cost (KRW) & Remark \\
\hline Wage (W) & $23,064,000$ & Except the bonus \\
Fuel Cost (FC) & $9,758,560$ & Light oil, LPG, volatile oil \\
Insurance (I) & $1,005,375$ & \\
Maintenance Cost (MC) & 659,057 & \\
Tax (T) & 229,240 & Apply the miscellaneous expenses \\
General Cost (GC) & $2,767,811$ & \\
Total & $37,484,043$ & \\
\hline
\end{tabular}

Notes: (1) For the labor cost, we apply the monthly payment cost (flat-rate payment + Overtime payment) for the transportation business. (2) For the fuel cost, Insurance, maintenance cost, tax and general cost, we apply the business cost (transportation cost) for the ground transportation (personal). (3) From here, the separate truck means the industry activities transferring the freight using the small truck (1ton or less) and medium truck (excess of 1 ton and less than 5 ton). Sources: (1) KSIS (2008). Transportation General. (2) ML (2008-2007). A study on the analysis of actual conditions on 2006 wage structure

Table 2: Gangseo agricultural wholesale market 1 day (24 hours) freight (fruits) parking vehicle condition (Year 2006)

\begin{tabular}{lllll}
\hline Total & 1.5 ton and less & 2.5 ton and less & 4.5 ton and less & Excess of 4.5 ton \\
\hline 1,257 & 924 & 172 & 100 & 61
\end{tabular}

Note: Date of survey is based on one day, 24 hours from 07:00 to the next day 07:00 (year 2006). Source: Seoul Agricultural \& Marine Products Corp., 2009. Annual reports for the agricultural and fishery transaction (Unit: Ton, 1,000,000 KRW)

Table 3: Transaction records by corporation at Gangseo agricultural wholesale market (Year 2007), (Unit: Ton, 1,000,000 KRW)

\begin{tabular}{|c|c|c|c|c|c|}
\hline \multirow[b]{3}{*}{ Corporation name } & \multirow{2}{*}{\multicolumn{2}{|c|}{ Records of transaction }} & \multirow{3}{*}{$\begin{array}{l}\text { Number of annual } \\
\text { transaction day }\end{array}$} & \multicolumn{2}{|c|}{ Daily average } \\
\hline & & & & \multirow{2}{*}{$\begin{array}{l}\text { Transaction } \\
\text { quantity }\end{array}$} & \multirow{2}{*}{$\begin{array}{l}\text { Transaction } \\
\text { amount }\end{array}$} \\
\hline & Quantity & Amount & & & \\
\hline Total & 499,059 & 595,678 & 307 & 1,626 & 1940 \\
\hline $\begin{array}{l}\text { Seobu fruit and vegetable } \\
\text { corporation }\end{array}$ & 84,419 & 82,075 & 307 & 275 & 267 \\
\hline $\begin{array}{l}\text { Gangseo national agricultural } \\
\text { cooperative federation }\end{array}$ & 91,290 & 99,452 & 307 & 297 & 324 \\
\hline $\begin{array}{l}\text { Gangseo fruit and vegetable } \\
\text { corporation }\end{array}$ & 72,126 & 64,749 & 307 & 235 & 211 \\
\hline market-wholesaler & 251,234 & 349,402 & 307 & 818 & 1138 \\
\hline
\end{tabular}

Source: MFAFF (2008- 2007) Statistical Yearbook of Agricultural \& Marine Wholesale Market

Table 4: Transaction results of the market wholesaler at Gangseo agricultural wholesale market (Year 2007) (Unit: Ton, 1,000,000 KRW)

\begin{tabular}{llll}
\hline Division & Transaction quantity & Transaction amount & Unit amount (KRW/Ton) \\
\hline Vegetables & 143,531 & 176,981 & $1,233,051$ \\
Fruit & 107,702 & 172,421 & $1,600,908$ \\
Total & 251,234 & 349,402 & $1,390,743$ \\
\hline
\end{tabular}

Source: Seoul Agricultural and Marine Products Corp, 2008. Annual reports for the agricultural and fishery transaction

Table 5: Calculation of accumulation cost for market wholesaler

\begin{tabular}{|c|c|c|c|c|}
\hline \multirow[b]{2}{*}{ Division } & \multirow[b]{2}{*}{$\begin{array}{l}\text { Transaction amount } \\
(1,000,000 \mathrm{KRW})\end{array}$} & \multirow[b]{2}{*}{ Social discount rate } & \multicolumn{2}{|c|}{ Accumulation cost $(1,200 \mathrm{KRW})$} \\
\hline & & & Per 1 day & Per time \\
\hline Vegetables & 176,981 & $5.5 \%$ & 26,668 & 1,111 \\
\hline Fruit & 172,421 & $5.5 \%$ & 25,981 & 1,083 \\
\hline Total & 349,402 & $5.5 \%$ & 52,650 & 2,194 \\
\hline
\end{tabular}

Table 6: Calculation of congestion accumulation cost of market wholesaler (based on the quantities of 2007) (Currency Unit: 1,200 KRW per \$1)

\begin{tabular}{|c|c|c|c|c|c|c|}
\hline \multirow[b]{2}{*}{ Division } & \multicolumn{3}{|l|}{ Daily cost } & \multicolumn{3}{|c|}{ Cost per time } \\
\hline & Congestion & Accumulation & Total & Congestion & Accumulation & Total \\
\hline Vegetables & 32,556 & 26,668 & 59,224 & 1,357 & 1,111 & 2,468 \\
\hline Fruit & 24,429 & 25,981 & 50,411 & 1,018 & 1,083 & 2,100 \\
\hline Total & 56,986 & 52,650 & 109,635 & 2,374 & 2,194 & 4,568 \\
\hline
\end{tabular}


Am. J. Agri. \& Biol. Sci., 7 (1): 28-35, 2012

Table 7: Transaction quantity and transaction amount by main item of market wholesaler (Year 2007) (Unit: kg, KRW)

\begin{tabular}{|c|c|c|c|}
\hline & Item & Total quantity & Total cost \\
\hline \multirow[t]{8}{*}{ Fruit and vegetables } & Watermelon & $23,431,039$ & $24,217,839,047$ \\
\hline & Oriental melon & $5,283,681$ & $10,898,109,639$ \\
\hline & Tomato & $11,155,089$ & $17,682,998,414$ \\
\hline & Grape & $9,647,777$ & $24,922,927,066$ \\
\hline & Peach & $7,234,743$ & $13,543,878,442$ \\
\hline & Apple & $12,281,197$ & $25,441,104,984$ \\
\hline & Pear & $6,765,887$ & $12,509,645,357$ \\
\hline & Citrus & $17,643,256$ & $22,474,003,831$ \\
\hline \multirow[t]{9}{*}{ Vegetables } & White radish & $13,984,125$ & $7,079,707,676$ \\
\hline & Chinese cabbage & $10,938,969$ & $5,639,238,729$ \\
\hline & Lettuce & $1,059,498$ & $1,958,781,197$ \\
\hline & Cucumber & $6,658,510$ & $8,564,955,552$ \\
\hline & Chili (pepper) & $2,603,775$ & $7,155,552,353$ \\
\hline & Onion & $12,716,598$ & $5,821,272,260$ \\
\hline & Carrot & $3,278,226$ & $1,864,587,529$ \\
\hline & Potato & $7,207,556$ & $5,599,366,241$ \\
\hline & Total & $151,889,924$ & $195,373,968,317$ \\
\hline
\end{tabular}

Source: Seoul Agricultural and Marine Products Corp 2008. Annual reports for the agricultural and fishery transaction

Table 8: Calculation of congestion accumulation cost by main item (based on the quantities of year 2007) (Currency Unit: 1,200 KRW)

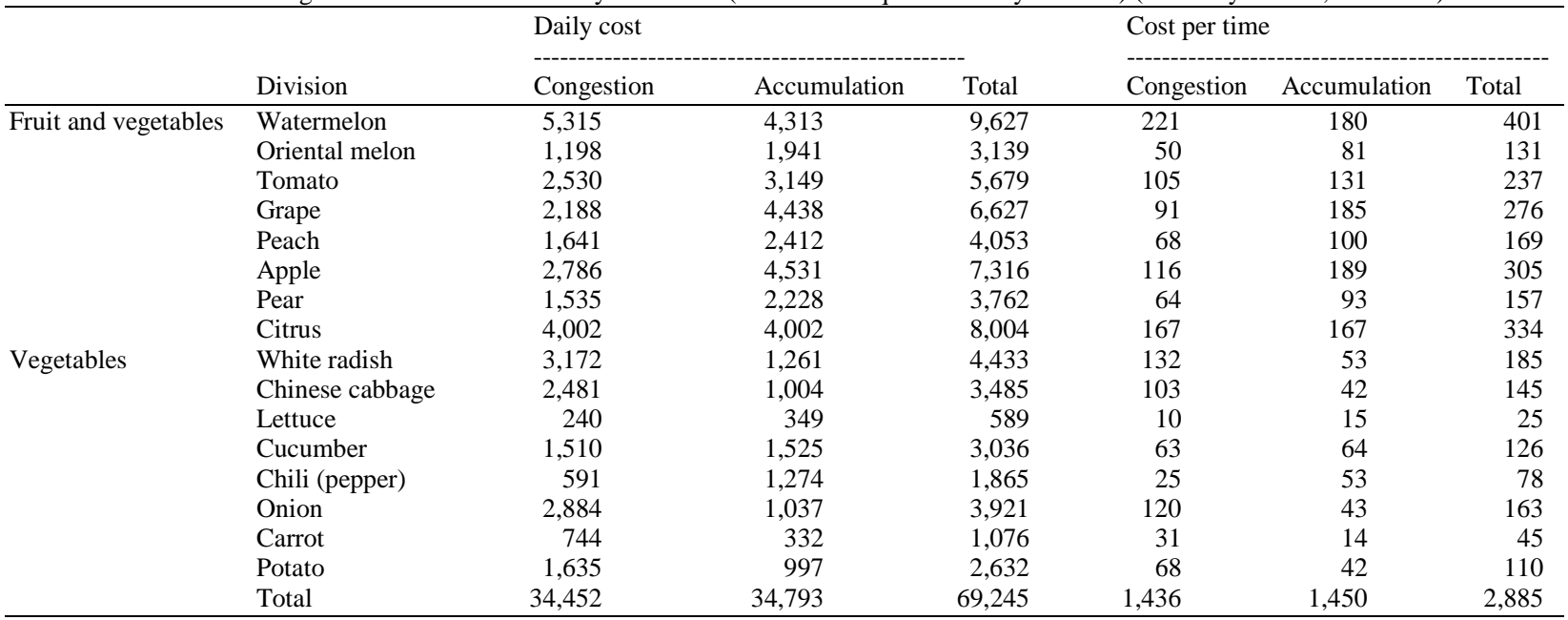

Calculation of congestion accumulation cost by product family: The congestion accumulation cost by product family for Gangseo agricultural wholesale market in 2007 was calculated as the sum of the accumulation cost by item based on the yearly carryingin quantities and the congestion cost of the truck related to the market wholesaler as per Table 6 . The congestion accumulation cost for the vegetables and fruit per day of the market wholesaler is 59,224,000 KRW, and $50,411,000 \mathrm{KRW}$ respectively. The total cost was calculated as 109,635,000 KRW per day. On the other hand, the cost per time was calculated at 2,468,000 KRW, 2,100,000 KRW, and 4,568,000 KRW respectively.

Calculation of congestion/accumulation cost by main item:

Condition for the total of dealing by main item of market wholesaler at Gangseo agricultural wholesale market: Based on data from 2007, Table 7 below shows the market wholesaler's total transaction quantity and transaction amount, by main item at Gangseo agricultural wholesale market. In looking at the total transaction quantities of fruit and vegetables, watermelon and radish tops the charts at 23,431 tons and 13,984 ton respectively.

Calculation of cost by main item: Based on data from 2007, the congestion accumulation cost by main product for the market wholesaler at Gangseo was calculated as the sum of the accumulation cost by item based on the carrying-in quantities and the congestion cost of the truck related to the market wholesaler as per Table 8 . The congestion accumulation cost per day for the main item of the market-wholesaler was 34,452,000 KRW, 34,793,000 KRW, and 69,245,000 KRW respectively, and the cost per time was calculated as 1,436,000 KRW, 1,450,000 KRW, and 2,885,000 KRW respectively. 
Am. J. Agri. \& Biol. Sci., 7 (1): 28-35, 2012

Table 9: Comparison of the required time of the product carrying-in to the preparation time for sale time

\begin{tabular}{|c|c|c|c|c|c|c|c|c|c|c|c|}
\hline \multirow[b]{3}{*}{ Division } & & \multicolumn{5}{|l|}{ Auction system } & \multirow[b]{3}{*}{ Transfer } & \multicolumn{4}{|c|}{ Market-wholesaler system } \\
\hline & & \multicolumn{5}{|c|}{ Carrying-in $\sim$ preparation for sale } & & \multicolumn{4}{|c|}{ Carrying-in $\sim$ preparation for sale } \\
\hline & & $\begin{array}{l}\text { Carrying- } \\
\text { in time }\end{array}$ & $\begin{array}{l}\text { Total } \\
\text { time } \\
\text { (min) }\end{array}$ & $\begin{array}{l}\text { Loading and } \\
\text { unloading } \\
\text { queuing }\end{array}$ & $\begin{array}{l}\text { Loading } \\
\text { and } \\
\text { unloading }\end{array}$ & $\begin{array}{l}\text { Auction } \\
\text { (queuing) }\end{array}$ & & $\begin{array}{l}\text { Carrying } \\
\text { in time }\end{array}$ & $\begin{array}{l}\text { Total } \\
\text { time } \\
(\mathrm{min})\end{array}$ & $\begin{array}{l}\text { Loading and } \\
\text { unloading } \\
\text { queuing }\end{array}$ & $\begin{array}{l}\text { Loading } \\
\text { and } \\
\text { unloading }\end{array}$ \\
\hline \multirow[t]{8}{*}{$\begin{array}{l}\text { Fruit and } \\
\text { Vegetables }\end{array}$} & Watermelon & $\begin{array}{l}\text { Previous day } \\
12: 00 \sim 14: 00\end{array}$ & 1,440 & 90 & 60 & 1,260 & 30 & $\begin{array}{l}14: 00 \sim \\
21: 00\end{array}$ & 120 & 20 & 100 \\
\hline & $\begin{array}{l}\text { Oriental } \\
\text { melon }\end{array}$ & $\begin{array}{l}22: 00 \sim \\
24: 00 \cdot 00\end{array}$ & 220 & 20 & 60 & 120 & 20 & $\begin{array}{l}22: 00 \sim \\
1: 00\end{array}$ & 60 & 10 & 50 \\
\hline & Tomato & $\begin{array}{l}22: 00 \sim \\
24: 00: 00\end{array}$ & 180 & 20 & 50 & 90 & 20 & $\begin{array}{l}22: 00 \sim \\
1: 00\end{array}$ & 60 & 10 & 50 \\
\hline & Grape & $\begin{array}{l}22: 00 \sim \\
24: 00: 00\end{array}$ & 240 & 20 & 100 & 90 & 30 & $\begin{array}{l}22: 00 \sim \\
1: 00\end{array}$ & 90 & 10 & 80 \\
\hline & Peach & $\begin{array}{l}22: 00 \sim \\
24: 00: 00\end{array}$ & 230 & 20 & 60 & 120 & 30 & $\begin{array}{l}22: 00 \\
2: 00\end{array}$ & 80 & 10 & 70 \\
\hline & Apple & $\begin{array}{l}23: 00 \sim \\
1: 00\end{array}$ & 680 & 60 & 50 & 540 & 30 & $\begin{array}{l}22: 00 \sim \\
1: 00\end{array}$ & 60 & 10 & 50 \\
\hline & Pear & $\begin{array}{l}23: 00 \sim \\
1: 00\end{array}$ & 680 & 60 & 50 & 540 & 30 & $\begin{array}{l}22: 00 \sim \\
2: 00\end{array}$ & 60 & 10 & 50 \\
\hline & Citrus & $\begin{array}{l}23: 00 \sim \\
1: 00\end{array}$ & 150 & 20 & 20 & 90 & 20 & $\begin{array}{l}23: 00 \sim \\
1: 00\end{array}$ & 40 & 10 & 30 \\
\hline \multirow[t]{8}{*}{ Vegetables } & $\begin{array}{l}\text { White } \\
\text { radish }\end{array}$ & $\begin{array}{l}18: 00 \sim \\
20: 00\end{array}$ & 210 & 60 & 90 & 60 & - & $\begin{array}{l}17: 00 \sim \\
22: 00\end{array}$ & 130 & 30 & 100 \\
\hline & $\begin{array}{l}\text { Chinese } \\
\text { cabbage }\end{array}$ & $\begin{array}{l}18: 00 \sim \\
20: 00\end{array}$ & 210 & 60 & 90 & 60 & - & $\begin{array}{l}17: 00 \sim \\
22: 00\end{array}$ & 130 & 30 & 100 \\
\hline & Lettuce & $\begin{array}{l}17: 00 \sim \\
19: 00\end{array}$ & 80 & 10 & 30 & 30 & 10 & $\begin{array}{l}19: 00 \sim \\
23: 00\end{array}$ & 40 & 10 & 30 \\
\hline & Cucumber & $\begin{array}{l}17: 00 \sim \\
19: 00\end{array}$ & 100 & 10 & 50 & 30 & 10 & $\begin{array}{l}20: 00 \sim \\
24: 00: 00\end{array}$ & 60 & 10 & 50 \\
\hline & $\begin{array}{l}\text { Chili } \\
\text { (pepper) }\end{array}$ & $\begin{array}{l}17: 00 \sim \\
19: 00\end{array}$ & 100 & 10 & 50 & 30 & 10 & $\begin{array}{l}20: 00 \sim \\
24: 00: 00\end{array}$ & 70 & 10 & 60 \\
\hline & Ónion & $\begin{array}{l}18: 00 \sim \\
20: 00\end{array}$ & 140 & 10 & 50 & 60 & 20 & $\begin{array}{l}21: 00 \sim \\
1: 00\end{array}$ & 110 & 10 & 100 \\
\hline & Carrot & $\begin{array}{l}18: 00 \sim \\
20: 00\end{array}$ & 150 & 10 & 50 & 60 & 30 & $\begin{array}{l}21: 00 \sim \\
1: 00\end{array}$ & 130 & 10 & 120 \\
\hline & Potato & $\begin{array}{l}18: 00 \sim \\
20: 00\end{array}$ & 150 & 10 & 50 & 60 & 30 & $\begin{array}{l}21: 00 \sim \\
1: 00\end{array}$ & 130 & 10 & 120 \\
\hline
\end{tabular}

Source: SAMPC (2007). Annual reports for the agricultural and fishery transaction

Comparison of operational time by system: As shown in Table 9, when comparing the required time by operating systems, the carrying-in time for the auction system is an hour faster than the market wholesaler system and the width of the carrying-in time in the market wholesaler system is 1 2 times faster than that in the auction system. In comparing the required time of the quantity carrying-in to the preparation for sale time, we can conclude that the auction system requires 4 times that of the market wholesaler system for the fruits and vegetables, and for the vegetables, the auction system requires 1.4 times that of the market wholesaler system. In comparing the results of the vegetables versus the fruits and vegetables, the reason that it takes a less required time by transaction system relatively is that the fruits and vegetables start the auction late as it has the storage issue.

Moreover, the difference of the time between the auction system and the market wholesaler system occurs from auction (queuing) and transfer time mainly. The auction system and the market wholesaler system show similar times for the loading and unloading time and the loading and unloading queuing time, with the exception of water melon, apple, and pear.

\section{DISCUSSION}

Comparison of the efficiency by system through the calculation of cost: Table 10 shows the results by calculating the required cost according to the congestion accumulation using the required time from the product carrying-in by system to the preparation time for sale. When examining the time cost of the system operation by main item, watermelon has a time cost of the market wholesaler system of $8,825,000$ KRW less than that of the auction system. Therefore, we can see that watermelon is the item with the biggest difference in time cost. Then, analysis shows the following difference of time costs: apple at 3,150,000 KRW and pear at 1,620,000 KRW.

On the other hand, in calculating the total time cost of 16 main items into the amount of money based on the total treatment quantity of the market wholesaler at Year 2007 Gangseo agricultural wholesale market as the time cost of the market wholesaler system is a total of $16,854,000 \mathrm{KRW}$ less than that of the auction system, we can evaluate that the market wholesaler system has the transaction efficiency. 
Am. J. Agri. \& Biol. Sci., 7 (1): 28-35, 2012

Table 10: Comparison of congestion accumulation time per hour in the calculation of cost (Year 2007), (Unit: 1,200 KRW)

\begin{tabular}{|c|c|c|c|c|c|c|}
\hline \multirow[b]{2}{*}{ Division } & & \multicolumn{2}{|c|}{ Required time (hour) } & \multicolumn{2}{|c|}{ Required cost } & \multirow[b]{2}{*}{ Difference (C-D) } \\
\hline & & Auction system & $\begin{array}{l}\text { Market wholesaler } \\
\text { system }\end{array}$ & $\begin{array}{l}\text { Auction } \\
\text { system (C) }\end{array}$ & $\begin{array}{l}\text { Market wholesaler } \\
\text { system (D) }\end{array}$ & \\
\hline \multirow[t]{8}{*}{ Fruit \& Vegetables } & Watermelon & 24.00 & 2.00 & 9,627 & 802 & 8,825 \\
\hline & Oriental melon & 3.67 & 1.00 & 480 & 131 & 349 \\
\hline & Tomato & 3.00 & 1.00 & 710 & 237 & 473 \\
\hline & Grape & 4.00 & 1.50 & 1,104 & 414 & 690 \\
\hline & Peach & 3.83 & 1.33 & 647 & 225 & 422 \\
\hline & Apple & 11.33 & 1.00 & 3,455 & 305 & 3,150 \\
\hline & Pear & 11.33 & 1.00 & 1,777 & 157 & 1,620 \\
\hline & Citrus & 2.50 & 0.67 & 834 & 222 & 611 \\
\hline \multirow[t]{8}{*}{ Vegetables } & White radish & 3.50 & 2.17 & 646 & 400 & 246 \\
\hline & Chinese cabbage & 3.50 & 2.17 & 508 & 315 & 194 \\
\hline & Lettuce & 1.33 & 0.67 & 33 & 16 & 16 \\
\hline & Cucumber & 1.67 & 1.00 & 211 & 126 & 84 \\
\hline & Chili (pepper) & 1.67 & 1.17 & 130 & 91 & 39 \\
\hline & Onion & 2.33 & 1.83 & 381 & 300 & 82 \\
\hline & Carrot & 2.50 & 2.17 & 112 & 97 & 15 \\
\hline & Potato & 2.50 & 2.17 & 274 & 238 & 37 \\
\hline Total & - & - & 20,929 & 4,076 & 16,854 & \\
\hline
\end{tabular}

Namely, in the analysis results, we can see that the market-wholesaler system has a higher efficiency rate than the auction system in the time saved and the required cost. If we concretely mention the results analyzed in this study, when we calculate total time cost of 16 main items into the amount utilizing the required time from the agricultural carrying-in to the preparation for sales by the transaction system at the agricultural wholesaler market, as the required time of the marketwholesaler system is less than that of the auction system, the market-wholesaler system demonstrates better transaction efficiency.

\section{CONCLUSION}

Established in 2004, Gangseo agricultural wholesale market operates the first market-wholesaler system in Korea. It was introduced to provide a way to counter any glitches in the market that may lead to a drop of product value for agriculture products, where freshness is life, and enhance the effectiveness.

The question has been raised over how much the introduction of the market-wholesaler system contributes to raising the efficiency of agricultural distribution through the rapid movement of logistics and the minimization of the distribution step within the wholesale market currently.

Therefore, in this study, we converted the time reduction of the operation, according to the difference of the transaction method during the introduction of the market-wholesaler system into the amount, through the estimates of congestion and accumulation cost and examined its economic feasibility.

Particularly, in the analysis by item results, watermelon had the greatest difference of time cost. The results studied in this study suggest that we must explore the conversion to a more low-cost high efficiency structure by improving the problem of the low-efficiency structure and accepting the auction system for the past twenty years as the main transaction method of the agricultural wholesale market in Korea.

Therefore, if the market wholesaler system is expanded and introduced into the 32 agricultural wholesale market system of Korea, we can expect that the transaction efficiency within the agricultural wholesale market will be enhanced and the efficiency of the whole agricultural distribution system will see the much needed improvements. However, the push for a change of the transaction system within the agricultural wholesale market in Korea is meeting with the great opposition and resistance by the group with the vested right, which get the gain easily under the existing auction system. As we expect such resistance will become stronger in the future, the change of the wholesale market transaction system must be supported and driven by the government's strong political movement to meet with the establishment purpose of the agricultural wholesale market, in order to guarantee the protection of the interests of the producer and the customer.

\section{AKNOWLEDGEMENT}

This study was supported by Konkuk university research fund.

\section{REFERENCES}

Goss, R.O., 1974. The Cost of Ships' Time. 1st Ed., H.M.S.O., London, pp: 45. ISBN: 0116302860, 9780116302861 
Jansson, J.O. and D. Shneerson, 1982. Port economics. 1st Ed., MIT Press, Cambridge, ISBN: 02621002589780262100250

Kim, Y.D. and S.G. Kwon, 2005. Review of the first year of market-wholesaler system and future challenges. Korean J. Agriculture Management Policy, 32: 823-848.

KMI, 2002. A study on the economic effects of portlogistic industry. Korea Maritime Institute

KSIS, 2008. Summary of transportation. Korean Statistical Information System.

MFAFF, 2008-2007. Statistical yearbook of agricultural and marine wholesale market. Ministry for Food, Agriculture, Forestry and Fisheries.
ML, 2008-2007. A study on the analysis of actual conditions on wage structure. Ministry of Labor

SAMPC, 2007. Annual reports for the agricultural and fishery transaction. Seoul Agricultural and Marine Products Corporation.

Young-Tae, C. and K. Sung-Gui, 1993. Study on the estimate of the cost of ship's time in port. J. Korean Maritime, 16: 229-259.

Young-Tae, C. and K. Sung-Gui, 2002. Revisit to estimate the time cost of ships and cargoes in port. J. Korean Navigation Port Res., 26: 383-390. 